\title{
Collaborating with public relations students to promote library subject specialists
}

n fall 2015, a group of librarians, who

are members of the Library West Creative Team at the George A. Smathers Libraries at the University of Florida (UF), sought new methods for effectively reaching undergraduate students. Previous internal studies showed that when students think of the library, they think of study space, technology, materials, and the coffee shop, but rarely do they consider librarians and the services we provide.

To address this issue, the Journalism and Mass Communications librarian partnered with a senior-level Public Relations (PR) Campaigns class to take on the Humanities and Social Sciences Library West as a client for the spring 2016 semester.

The students were charged with raising awareness of the librarians and the vital role we play as subject specialists, rather than focusing on the physical library space. Under the direction of their professor, students met with us to develop a brand platform, a list of campaign issues, and a research plan that included survey and focus group data. Each competing group in the class developed a final campaign strategy that was presented to the library for later consideration.

\section{The process}

During the initial client meeting with the PR campaigns class, we carefully explained that we were looking for "a strategy to increase awareness of who the librarians are, and how they can be an instrumental part of student success." We were not interested in promoting the library as an entity, since getting students to enter the physical space was never an issue. Yet, in a 2016 student survey of library usage, staff assistance was ranked 9 out of 10 in importance of library services. Similarly, in another survey ${ }^{1}$ conducted four years earlier of more than 1,100 students across five campuses (including UF), only 3.9\% said they come to the library to consult with a librarian. "I don't know what I'm supposed to ask them about," explained one student in the comments. These survey results were presented to the students during the first client meeting to showcase exactly what they were up against.

At the second client meeting, students presented us with a draft of their survey and focus group questions prior to their initial data collection. While many of the questions appeared to effectively measure student awareness of librarians and the services they provide, several other questions still focused heavily on library space, such as which library on campus students preferred the most. In our feedback, we had to remind the PR students that this was meant to be a campaign focused on librarians, not library resources as a whole.

April Hines is Journalism and Mass Communications librarian, email: aprhine@uflib.ufl.edu, Hélène Huet is European Studies librarian in the George A. Smathers Library, email:hhuet@ufl.edu, Stacey Ewing is associate chair, LibraryWest, and coordinator of InfoCommons@ West, email: staewin@uflib.ufl.edu, and LeiLani Freund is university librarian/linguistics and health and human performance liaison at the University of Florida, email: leifreu@uflib.ufl.edu

C 2017 April Hines, Hélène Huet, Stacey Ewing, and LeiLani Freund 
During the data collection process, the class conducted a 13-question survey and collected 352 responses from a wide range of majors in the Humanities and Social Sciences. The students also led two peer focus groups and asked ten open-ended questions, such as "How would you describe what a librarian does?" One of the most revealing questions asked students "If you knew a librarian could assist you with would you ask for help?" $93 \%$ of respondents said they would look for assistance if they knew a librarian could help them locate scholarly research for assignments. Yet, $60 \%$ were unaware they had a subject librarian, and $77 \%$ were unsure of what a subject librarian might do. These results indicate that while students do need our help, they do not necessarily know we exist or the extent of our role.

Armed with the results, the class was then divided into four groups and each began the process of developing a strategic PR campaign plan. The plans included a brand platform, research analysis, message platform, strategies and tactics, and a proposed budget and timeline. These were

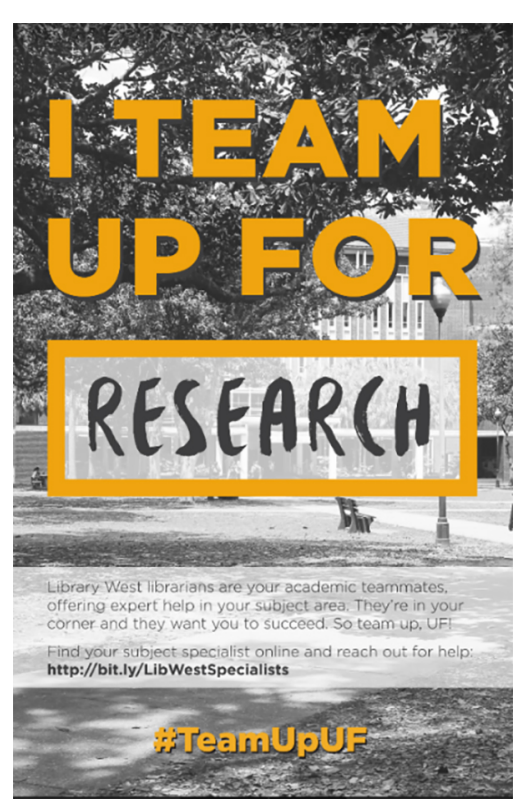

One of the Team Up Campaign Plan poster ideas. ing, we did not deem it appropriate for our academic setting. The key message of The Way to an A Starts Here was that contacting and interacting with a librarian is easier than ordering coffee, but students also need to view librarians as readily available experts. Some of the tactics proposed by this team were bus ads, posters, and an elevator wrap. The Ask West concept was to make sure students and faculty see librarians as relevant, specialized, and accessible. Some of the highlights of the campaign were a daylong Snapchat takeover by a librarian and the creation of an informational video featuring the UF's mascot to raise awareness of Library West's librarians.

The winning campaign in our eyes was Team Up UF. We liked their idea of representing librarians as academic teammates, joining forces with students to help them achieve academic success. The campaign showcased several tactics that we thought would be doable and effective, such as creating brief YouTube videos introducing librarian subject specialists and the resources they provide, or developing informational graphics to be distributed through social media and printed in professional qual-

ity campaign books that were given to the five library staff members who served as judges during the groups' final presentations at the end of the semester.

\section{The campaigns}

The four campaign plans offered a wide range of ideas. ${ }^{2}$ Knowledge is Sexy focused on humorous social media tactics, special events, and relationship-building. This campaign offered creative ideas such as incorporating a Tinder design (inspired by the popular dating app) into our advertising to show that knowledge is "desirable." While the idea was amus- within the library itself.

Ultimately, we decided to pick and choose from all the campaigns the ideas we liked best and also those that fit more with our library, our community, and our budget. We really liked the idea of having bus ads, for instance, but it proved too expensive. One of the tactics we implemented was the "Library West Top 10 Resource Guide" infographic ${ }^{3}$ listing our top ten resources. We distribute this handout during tabling events and fairs, as well as in library instruction sessions, and also maintain a stack by our research assistance desk.

Additionally, we have lightened up our so- 
cial media presence and created a Library West Snapchat filter. Teaming up with our student Library Ambassadors group, we organized a tabling event in front of the library, where we promoted the librarians and what we do, along with our "Top 10" resources through a "spin the wheel" game, using library swag as prizes.

Finally, one project we unveiled in June, is an elevator wrap featuring all the subject specialist librarians of Library West. The elevator wrap includes the slogan: "Librarians are on Your Team" and the hashtag \#TeamUpLibWest. As students wait for our slow moving elevators, it will now be hard to miss us.

\section{Assessment}

An important part of our project is maintaining focus on the user. Rather than assume that new initiatives are met with the approval of the user community, we have taken the first steps toward assessing satisfaction and effectiveness.

The "Library West Top 10 Resource Guide" infographic is very popular with librarian instructors and students. It has been viewed online 633 times between September 16, 2016, and May 1, 2017, and approximately 1,000 print copies were handed out within that timeframe. We will be investigating how the infographic is used, whether the number of uses remains high, and how often it needs updating.

The tabling event proved incredibly useful. Our tabling volunteers were enthusiastic about the opportunity to meet new, potential users (more than 100 people over 4 hours of time) and engage in one-on-one conversations about library services. Many visitors left their names and emails on a clipboard for our information. A further means of assessment would be to contact these students and find out if they are using the libraries more frequently after learning more about us.
All the PR campaigns emphasized use of social media, driving our decision to have one librarian in charge of our social media tools. This resulted in more posts and consistent promotion of our various events, workshops, talks, and services. We did notice that the Library West Facebook page gained 105 likes since August 16, 2016, which indicates a $12 \%$ increase after the campaign was instituted. Our proactive involvement on social media likely explains this increase.

The SnapChat filter was an obvious success. During the ten days it was active, October 3-12, 2016, library patrons responded very favorably to the filter, which saw 1,900 uses in photos that received 47,100 views. These numbers were particularly high given that campus closures for Hurricane Matthew had also occurred during this time.

The challenge for our group will be to maintain a high level of evaluation and assessment. The elevator wrap could potentially have a large impact. During the 2017 Spring semester finals week and in conjunction with a free pizza event, we conducted an initial awareness survey and will do a follow-up after the elevator wrap is installed at the same point in the fall 2018 semester. We have detailed statistics for research assistance desk questions and some for individual and group consultations with subject specialist librarians. We should be able to get a fairly accurate picture of desk activity before and after the wrap is installed, and some analysis of the types of questions asked.

We may also conduct informal interviews with the librarians to gather anecdotal evidence that our PR efforts have or have not generated more awareness of librarian services. A further step could include involving some of the librarians in designing a follow-up satisfaction survey for users who consult with a library specialist. 
Lastly, the poster session at ACRL itself yielded some important feedback and valuable conversations. ${ }^{4}$ Conference attendees expressed great interest in our initiatives. There were many "lightbulb" moments—-Yes, our university has a PR class-we could do that!" Although we had our favorite campaigns, we were reminded that the less lauded campaigns and ideas also had merit and proponents among our poster viewers.

\section{Future plans and afterthoughts}

The Library West Creative Team made the decision to choose and execute two ideas per semester, preferring to implement quality over quantity. Because of this, we now have a queue of future strategies drawn from the successful student campaign plans. To begin, our team was recently awarded an internally funded, graduate student internship grant, enabling us to hire a PR and marketing student to spend 20 hours per week assisting with fulfilling our favorite campaign ideas. This summer, with the intern's help, we created fun and engaging video profiles for all of the Library West subject librarians, ${ }^{5}$ as well as produce a series of promotional videos using the UF Gator mascot to introduce the students to librarians as their academic teammates.

To conclude, we have learned much from our collaboration with the students of the PR class. It has been incredibly useful to observe which strategies they felt would work best to gain the most attention from their peers. After all, who but the students themselves can tell us what they need and are looking for? We have learned that working together with students on the creation of marketing and outreach strategies needs to become the rule rather than the exception in our library and plan to reiterate this experience in the near future.

\section{Notes}

1. Michele J. Crump and LeiLani S. Freund, with contributions from Steve Carrico, et al., Meeting the needs of student users in academic libraries: Reaching across the great divide (Oxford, UK: Chandos Pub., 2012), 127-71.

2. Campaign books may be viewed in their entirety at the UF Institutional Repository, http://ufdc.ufl.edu/IR00009612/00001 /allvolumes (accessed May 26, 2017).

3. Diana Dombrowski, et al., "Library West Top 10 Resource Guide,” http://ufdc.ufl.edu /IR00008615/00001 (accessed May 26, 2017).

4. April Hines, Hélène Huet, Stacey Ewing, and LeiLani Freund, Team Up: Collaborating with Public Relations Students to Promote Library Subject Specialists, http://ufdc.ufl.edu /IR00009612/00006 (accessed May 26, 2017). See one example here: https://youtu.be/oTtUIvQnClQ (accessed May 26, 2017). $\boldsymbol{\text { z }}$

\section{Statement of ownership and management}

College $\&$ Research Libraries News is published 11 times a year (monthly, combining July/August) by the American Library Association, 50 E. Huron St., Chicago, IL 60611. American Library Association, owner; David Free, editor. Second-class postage paid at Chicago, Illinois. Printed in the U.S.A. As a nonprofit organization authorized to mail at special rates (DMM Section 423.12), the purposes, function, and nonprofit status of this organization and the exempt status for federal income tax purposes, have not changed during the preceding 12 months.

Extent and nature of circulation. ("Average" figures denote the number of copies printed each issue during the preceding twelve months; "Actual" figures denote the number of copies of single issues published nearest to filing date.) Total number of copies (net press run): Average, 11,370; Actual, 11,466. Total paid/ requested subscriptions: Average, 10,691; Actual, 10,749.
Sales through dealers and carriers, street vendors, counter sales, and other non-USPS paid distribution: not applicable. Other classes mailed through the USPS: not applicable. Total paid and/or requested circulation: Average, 10,691 Actual, 10,749. Free distribution by mail: Average, 126; Actual, 80. Free distribution outside the mail: Average, 0; Actual, 0. Total free distribution: Average, 126; Actual, 80. Total distribution: Average, 10,817; Actual, 10,829. Copies not distributed: Office use, leftover, spoiled: Average, 553; Actual, 637. Total (sum of previous entries): Average, 11,370; Actual, 11,4656. Percent paid and/or requested circulation: Average, 98.8\%; Actual, $99.2 \%$.

Statement of ownership, management, and circulation (PS Form 3526, July 2014) for 2017 filed with the United States Postal Service, Postmaster in Chicago, Illinois, August 4, 2017. 